\title{
A Strong Voice for Keeping America Strong
}

\section{A Profile of Senator Bourke Hickenlooper}

\author{
EDWARD L. SchapsMEIER \\ FREDERICK H. SCHAPSMEIER
}

Bourke Blakemore Hickenlooper of Cedar Rapids represented Iowa in the United States Senate for nearly a quarter of a century. His years of public service on the national level, from 1945 to 1969 , were exceeded in length only by William B. Allison of Dubuque (who served in the upper chamber from 1873 to 1909). The latter, however, served in an era when senators were chosen by state legislatures. In view of the fact that Hickenlooper also held various state offices for ten years (four as state representative, four as lieutenant governor, and two as governor), he was designated the "winningest" Republican in Iowa history. ${ }^{1}$

Born at Blockton in southwest Iowa on July 21, 1896, Bourke was the son of Nathan C. and Margaret A. Blakemore Hickenlooper. After attending public schools and earning a high school diploma at Blockton, he enrolled at Iowa State University in 1914. Bourke Hickenlooper interrupted his college education to enlist in the army and served in France as a second lieutenant with the 3rd Battalion, 339th Field Artillery. After the war he reentered Iowa State and graduated in 1919 with a degree in industrial science. In that same year he entered the University of Iowa Law School and graduated with a law degree in 1922. Hickenlooper moved to Cedar Rapids and practiced

1. Cedar Rapids Gazette, 6 September 1971, quoted in "Iowa State Senate Memorial Resolution," Memorial Addresses and Other Tributes in the Congress of the United States on the Life and Contributions of Bourke B. Hickenlooper (Washington, D.C., 1972), vii. 
law until being elected to the Iowa House of Representatives in 1934. He proved ultimately to be an extraordinarily successful campaigner by winning senatorial elections in 1944, 1950, 1956, and $1962 .^{2}$

Republican colleagues regarded Hickenlooper as the most "consummate skeptic" in the Senate. ${ }^{3}$ He displayed a conservative skepticism over the development of the welfare state and subsequent deficit spending needed to finance expanding federal programs. In denying that he was a reactionary for opposing President Harry Truman's Fair Deal proposals, Hickenlooper informed a constituent of his concern over the "utter lack of responsibility in the Administration's increased tax and increased spend[ing] policy, combined with the mounting national debt and international problems that are terrific and that must be solved in our own interest." ${ }^{4}$ Because he disliked unbalanced budgets and waste in government, Hickenlooper was a vigorous, self-appointed watchdog over the activities of Washington's many bureaucrats.

Senator Hickenlooper was a stalwart midwesterner, who, in the words of the New Republic's TRB, "ought to be holding a pitchfork in Grant Wood's 'American Gothic.' "5 He had a reputation as the "hardest-working Republican in congress," but was also dubbed the "most anonymous man in the Senate." Hickenlooper was a highly respected member of the Senate Foreign Relations Committee for twenty years, six as ranking Republican, but he never gained the national prominence of his Democratic counterpart, J. William Fulbright of Arkansas. While serving as chairman of the Senate Republican Policy Committee from 1962 to 1968 , he was overshadowed by the

2. He successively defeated Guy M. Gillette (incumbent), Albert J. Loveland, R. M. Evans, and Albert B. Smith.

3. "Bourke Hickenlooper is Dead: Former Iowa Senator Was 75," New York Times, 5 September 1971, in New York Times Biographical Edition (New York, 1979), 278.

4. Hickenlooper to Dick Mason, 6 May 1949, "Political-General, 1949," Bourke B. Hickenlooper Papers, Herbert Hoover Presidential Library, West Branch, Iowa (hereafter cited as BBHP).

5. Richard L. Strout, TRB, Views and Perspectives on the Presidency (New York, 1979), 278.

6. Clipping, Cleveland Plain Dealer, 24 May 1959, “Clippings, 1959-Personal," BBHP. 
personal dominance of Senate Minority Leader Everett M. Dirksen of Illinois. ${ }^{7}$ Hickenlooper was a follower not a leader. Only two major pieces of legislation bear his name: the ColeHickenlooper Atomic Energy Act of 1954 (authorizing development of nuclear power by private utilities) and the Hickenlooper Amendment to the Foreign Aid Act of 1963 (cutting off United States assistance to any country which expropriated American-owned property). ${ }^{8}$

His humble demeanor and low profile in national politics did not prevent Hickenlooper from being regarded as a tenacious anti-Communist crusader and cold war warrior. As a man who believed in fairness and strict due process he did not emulate the witch-hunt tactics of either Patrick McCarran or Joseph R. McCarthy. Hickenlooper feared the threat of internal subversion at home and the threat of Communism abroad. His stance stemmed from an old-fashioned patriotism dictating that the United States, as leader of the Free World, must defend democracy and the concept of self-determination all over the world. To achieve these foreign policy goals Hickenlooper believed that the United States should maintain a strong military establishment-including a monopoly on the atomic bomb - so that it could either deter or defeat Communist aggression anywhere on the globe. He supported negotiating with the Soviet Union and other Communist regimes only where the United States did "not negotiate from a standpoint of weakness

7. Members of the committee were: Hickenlooper; Dirksen; Thomas Kuchel, California; Frank Carlson, Kansas; Norris Cotton, New Hampshire; Roman Hruska, Nebraska; Kenneth Keating, New York; Thruston Morton, Kentucky; Leverett Saltonstall, Massachusetts; Hugh Scott, Pennsylvania; Margaret Chase Smith, Maine; Milton Young, North Dakota; Barry Goldwater, Arizona; and Winston Prouty, Vermont. The committee was charged with preparing party policy statements, keeping records of all votes, circulating analyses of pending bills, acquiring research material, providing summaries of laws, supplying professional assistance, and distributing minutes. See "Senate Republican Policy Committee Minutes," 17 January 1963, BBHP.

8. While voting for foreign aid bills, Hickenlooper fought against making a host of nations permanently dependent on United States assistance. He thought that recipient nations should undertake internal reforms and initiate self-help programs to continue being eligible for American aid. See Hickenlooper to Kenneth M. Bowen, 31 January 1963, "Legislation-Foreign Aid, 1962-1963," BBHP. 
where the result would be surrender by the Free World." ${ }^{\prime 9}$ When a friend in Iowa, the editor of the Mason City Globe Gazette, criticized him for voting to cut the appropriation of the Disarmament Agency (the creation of which he had opposed), Hickenlooper defended his stance: "I continue to revert to the experience of the Pilgrim Fathers and others in the wilderness of the new world when they went to church on Sunday but carried their flintlocks and stacked them conveniently in the corner for immediate use if the savages attack."10

One of Hickenlooper's first important votes after entering the Senate was to support the United States' participation in the newly founded United Nations. This represented a switch from his pre-World War II isolationism. He defended his position by explaining to a constituent, "I believe we must take our proper and enlarged part in international matters." ${ }^{11}$ Hickenlooper supported President Truman's foreign policy of containing Communism. He voted for $\$ 400$ million in military and economic aid to Greece and Turkey in 1947, for the Marshall Plan in 1948, and for ratification of the North Atlantic Treaty Organization in 1949. Hickenlooper supported foreign aid expenditures as a means of preventing underdeveloped nations from falling to Communism, but he remained critical of bureaucratic mismanagement. He justified his voting record over the years by arguing that such monetary outlays were "in our national interests of helping to build the Free World into a bulwark to resist Communist imperialism . . . through helping nations engaged in the revolution of 'rising expectations' to achieve their development peacefully." He also reminded a critic, "I have consistently criticized inefficiency, waste, corruption, and misdirection of these programs." 12

Hickenlooper believed America should preserve its monopoly of the atomic bomb as a vital deterrent to Soviet imperialism. While a member of the Joint Committee on Atomic Energy

9. Hickenlooper to Moss M. Tangen, 18 February 1965, BBHP.

10. Hickenlooper to W. Earl Hall, 11 June 1963, "Legislation-Arms Control and Disarmament Act, 1963-1964," BBHP.

11. Hickenlooper to A. E. Baldridge, 10 November 1945, "Personal-Baldridge, A. E.," BBHP.

12. Hickenlooper to David Baur, 24 September 1965, "Legislation-Foreign Aid, August 1965-April 1966," BBHP. 


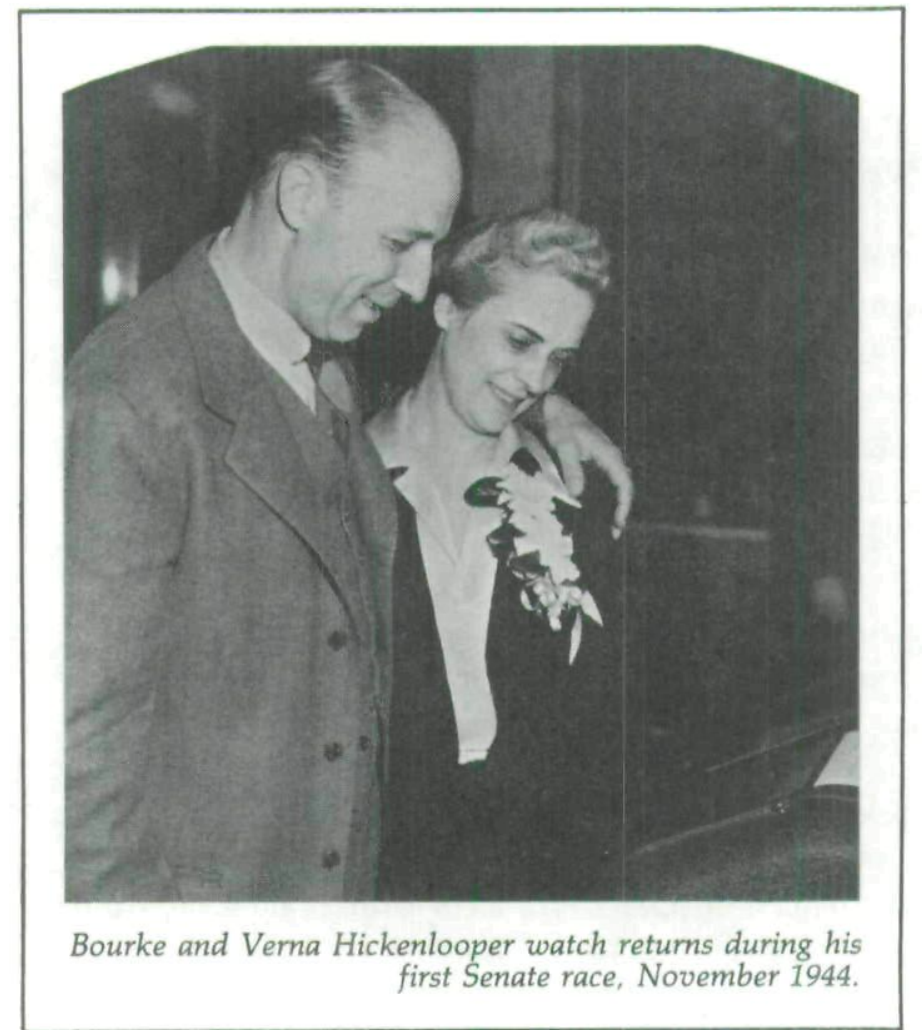

he maneuvered unsuccessfully to secure General Leslie R. Groves's appointment as chairman of the Atomic Energy Commission (AEC). The AEC was established under the authorization of the Atomic Energy Act of 1946 which transferred management, regulation, research, and future development of atomic energy for both military and peacetime use from the secret Manhattan Project (headed by Groves) to the civiliancontrolled AEC. During debate on the Atomic Energy Bill, Hickenlooper supported the concept of civilians controlling the commission but desired military control over nuclear weapons to ensure protection of atomic secrets. Fellow Iowan Henry A. Wallace, secretary of commerce in the Truman administration, complained to the president that the measure was too "extreme in the matter of security regulations and violations." 13 David

13. Wallace to Truman, 9 November 1945, quoted in The Price of Vision: The Diary of Henry A. Wallace, 1942-1946, ed. John Morton Blum (Boston, 1973), 510. 
Lilienthal, who agreed with Wallace, had worked with Dean Acheson to formulate an international plan to share atomic information. He also felt free scientific inquiry would be inhibited by excessive secrecy. Truman chose Lilienthal-not Groves-in 1946 to be chairman of the newly created AEC. Hickenlooper eventually voted for Lilienthal's confirmation as chairman of the AEC, despite charges leveled by Senator Kenneth McKellar that Lilienthal sympathized with Communism. McKellar had been conducting a personal vendetta against Lilienthal for some time and Hickenlooper discounted his allegations.

Hickenlooper's concern for national security grew with the 1945 revelation that a Russian spy ring had been operating during the war in Canada. ${ }^{14} \mathrm{He}$ did not want to share information with either Canada or Great Britain, let alone the Soviet Union. Confiding his fears to General Dwight D. Eisenhower, then chief of staff, Hickenlooper stated, " . . . I do not believe that the time has come when we should either altruistically disclose all of our military secrets or abandon further development [of atomic weapons]."15

In 1949 the AEC's Argonne Laboratory reported the disappearance of an ounce of the uranium isotope, U-235. Soon after this incident, it also became known that an AEC research fellowship had been awarded to an acknowledged member of the American Communist party. Now a member of the Joint Congressional Committee on Atomic Energy, Senator Hickenlooper publicly charged Lilienthal with "incredible mismanagement." 16

I want to re-emphasize that I have not in any degree impugned Mr. Lilienthal's personal honesty nor his personal patriotism to his country. I believe he is sincere in his beliefs and his policies. It is with his policies and with a continuation of those policies that I sharply disagree. ${ }^{17}$

Even though liberals labeled Hickenlooper's attack as un-

14. For more details see The Report of the Royal Commission to Investigate Disclosures of Secret and Confidential Information to Unauthorized Persons (Ottawa, 1946).

15. Hickenlooper to Eisenhower, 3 June 1946, "AEC Commission-Groves, General Leslie R., March 1946-June 1947," BBHP.

16. Press Release, 22 May 1949, "Investigations of Hickenlooper, Bourke B.," BBHP.

17. Press Release, 26 May 1949, ibid. 
just, he did not cease his efforts to remove Lilienthal. He believed that the AEC chairman could not observe the tight security regulations under which he had to operate. Publicly Lilienthal denied being guilty of poor administration, but in his personal journal he admitted that the Argonne "lab's property procedure and our own [AEC's] are sloppy and lax." ${ }^{18}$ Lilienthal also explained his refusal to have the FBI conduct investigations to establish security clearances for AEC research scholarship recipients: he personally detested secrecy and undue security precautions as conflicting with academic freedom and scholarly inquiry, so "we decided not to ask for FBI investigations." 19 The result of this decision was that Hans Freistadt, an Austrian-born student at the University of North Carolina and a self-admitted Communist, received an AEC fellowship.

Democrats on the Joint Committee on Atomic Energy quickly sought to terminate its investigation of Lilienthal to limit the political fallout. Hickenlooper, on the other hand, attempted to deepen the probe. He also resented President Truman's lack of cooperation with the joint committee. The majority report ultimately did vindicate Lilienthal. Republican senator Arthur H. Vandenberg of Michigan befriended Lilienthal but nevertheless acknowledged to Hickenlooper that his investigatory efforts were salutary. "My considered verdict is," he wrote, "that the inquiry disclosed many needs for reforms and improvement; ... that the commission itself-and thus the country-immediately benefitted from these lessons; and that this whole vast atomic enterprise is bound to be safer as a result of your courageous activities." 20

On February 15, 1950, only a short while after denying Hickenlooper's charge, Lilienthal resigned as chairman of the AEC. In his diary Lilienthal asserted that the "reason was not Hickenlooper... nor the terrible kind of responsibility involved." The "basic reason" for quitting was "secrecy." The latter, he wrote, "was so contrary to my experience ... that it

18. David E. Lilienthal, The Journals of David E. Lilienthal, 6 vols. (New York, 1964-), vol. 2, The Atomic Energy Years, 1945-1950, 531.

19. Ibid., 530.

20. Vandenberg to Hickenlooper, 25 January 1950, in The Private Papers of Senator Vandenberg, ed. Arthur H. Vandenberg, Jr., with Joe Alex Morris (Boston, 1952), 358. 
poisoned the work; then made it actually distasteful." ${ }^{21}$ For just this reason Hickenlooper had wanted an experienced military man, such as General Groves, to be the custodian of atomic research and development; Groves had proved his ability to maintain tight security as head of the Manhattan Project. British physicist Klaus Fuchs's conviction for espionage, British scientist Donald Maclean's defection to Russia, and Ethel and Julius Rosenberg's trial all served to heighten Hickenlooper's apprehension over internal subversion and laxity of security in government agencies. ${ }^{22}$

$I_{N} 1950$ a fellow midwesterner and GOP Senate cohort, Joseph R. McCarthy, grabbed the public limelight by claiming in a speech given at Wheeling, West Virginia that the Truman administration refused to discharge fifty-seven known Communists from the State Department. The Senate majority leader, Scott W. Lucas of Illinois, sponsored Senate Resolution 231 authorizing a temporary subcommittee of the Foreign Relations Committee to hold hearings investigating McCarthy's sensational charges. Hickenlooper served on this subcommittee. Democrat Millard E. Tydings of Maryland was designated chairman. He was advised by Lucas: "It seems to me that McCarthy should either affirm or deny these charges. I tried to get him to do this on the floor of the Senate, and he refused."23

Partisan politics and controversy surrounded the Tydings Committee from the start. With midterm elections approaching, the Democrats wanted to discredit McCarthy while the Republicans saw an opportunity to exploit the Communist issue. By now Senator McCarthy had increased his list of supposed Communists in the State Department to eighty-one. When Senator Tydings took the position of judging the ac-

21. Lilienthal, Journals, vol. 4, The Road to Change, 1955-1959, 119.

22. For more details see Gregg Herken, The Winning Weapon: The Atomic Bomb in the Cold War, 1945-1950 (New York, 1980), 340-341. Herken labels Hickenlooper a "notorious anglophobe" (380). Although Hickenlooper disliked the socialist government in Britain, his aversion to sharing atomic secrets was to prevent exactly what occurred in the Fuchs and Maclean spy affairs. He did not want to share information with any country.

23. Memorandum, Lucas to Tydings, 27 February 1950, Box 20, Papers of Scott W. Lucas, Illinois State Historical Society, Springfield, Illinois. 
curacy of McCarthy's charges before the investigation started, committee member Henry Cabot Lodge claimed the hearing was "some sort of kangaroo court." 24 Hickenlooper tried to steer a middle course amid this whirlwind of political passion. To a constituent who criticized him for not publicly condemning those alleged Communists named by McCarthy, Hickenlooper defended his behavior by explaining: "I think this is the proper theory of presumption of innocence that surrounds any one until adequate proof is forthcoming." He also indicated that while being "utterly fair" it was also necessary that the investigation be conducted "vigorously and as deeply as possible. . . ." 25

At the first executive meeting of the Tydings Committee, Hickenlooper and Lodge, the only two Republican members, proposed calling Senator McCarthy before the subcommittee so that he might disclose privately whatever information he possessed. Majority Leader Lucas had made this same recommendation. The Democrats on the subcommittee, however, rejected this suggestion on procedure. McCarthy also notified Hickenlooper that Chairman Tydings refused to permit the Wisconsin senator to cross-examine witnesses appearing before the subcommittee. McCarthy insisted, "I sincerely hope that you and Senator Lodge make it clear that you have no part in this inexcusable failure to bring forth the truth in every manner possible." 26

At Hickenlooper's urging, the Tydings Committee did ask the State Department for the loyalty files of the eighty-one individuals accused by McCarthy. After examining eight files Hickenlooper concluded that they had been expurgated, yet he felt they were still sufficiently incriminating to make him highly skeptical of the efficacy of the Truman loyalty program: "I don't hesitate to say on this record that the ones I read I would say almost without exception I would not keep in the State Department." 27

24. Quoted in Thomas C. Reeves, The Life and Times of Joe McCarthy: A Biography (New York, 1982), 249.

25. Hickenlooper to Guy E. Hillier, 3 April 1950, "Disloyalty Investigations-Kenyon, Dorothy, 1950," BBHP.

26. McCarthy to Hickenlooper, 16 April 1950, "Disloyalty Investigations-McCarthy, Senator Joseph R., 1950-1951," BBHP.

27. Quoted in William F. Buckley, Jr., and L. Brent Bozell, McCarthy and His Enemies: The Record and Its Meaning (Chicago, 1954), 357. 
The Tydings Committee report-which represented the views of the Democratic majority-exonerated the State Department of any charges relating to alleged laxity in its security program while labeling McCarthy's accusations a "fraud and hoax." ${ }^{28}$ Neither Hickenlooper nor Lodge signed the report. They protested that the investigation was incomplete and constituted a whitewash of the State Department. Even Senator Margaret Chase Smith, no friend of McCarthy's, agreed with Hickenlooper that the Democrats on the Tydings Committee "made the fatal error of subjectively attempting to discredit McCarthy rather than objectively investigating and evaluating his charges." 29

After winning reelection for a second term in 1950, Hickenlooper renewed his demand for "a thorough and extensive housecleaning of the whole State Department." ${ }^{30} \mathrm{He}$ also called for Secretary of State Dean Acheson's resignation for having made a blundering speech in which he excluded South Korea from the United States' defense perimeter-thus seeming to invite an invasion by Communist North Korea. When President Truman relieved General Douglas MacArthur for advocating total military victory in Korea, Hickenlooper supported the deposed general. The Iowa senator even advised the use of atomic weaponry "whenever it can be materially decisive for victory." ${ }^{31}$

Erroneously believing Communism to be monolithic in nature, with the Soviet Union as leader of the Communist bloc, Hickenlooper opposed all trade with this group of nations. He also did not favor diplomatic recognition of the People's Republic of China or, after Fidel Castro came to power in Cuba, giving foreign aid to any nations "which continue to ship strategic material, including munitions, to Communist Cuba. ..." ${ }^{\prime 32}$ Hickenlooper thought the public should have

28. Quoted in Richard H. Rovere, Senator Joe McCarthy (Cleveland, 1966), 156.

29. Margaret Chase Smith, Declaration of Conscience, ed. William C. Lewis, Jr. (Garden City, N.Y., 1972), 9.

30. Quoted in Ronald J. Caridi, The Korean War and American Politics: The Republican Party as a Case Study (Philadelphia, 1969), 85.

31. Ibid., 175.

32. Hickenlooper to Ken Boatright, 31 January 1963, "Legislation-Foreign Aid, 1962-1963," BBHP. 
complete information about mainland China's fall to Communists and felt that the China White Paper did not reveal all the facts. He urged John Foster Dulles, when he became secretary of state in 1953, to issue another "special volume on United States-China relations" from 1941 to 1950. In addition he pressed for publication of all diplomatic papers of World War II "down through Cairo, Teheran, Yalta and Potsdam. . . ." Such volumes were subsequently published.

Hickenlooper was associated with the conservative wing of the Republican party led by Senator Robert A. Taft of Ohio, but he went to the party's 1952 national convention as an unpledged delegate. When the balloting began he voted for Dwight D. Eisenhower. During the ensuing campaign he worked hard for Eisenhower's election while criticizing the Democratic nominee, Governor Adlai E. Stevenson of Illinois, for advocating an end to testing atomic bombs. (Ironically, in 1963, Hickenlooper changed his mind and voted for the Test Ban Treaty.) Hickenlooper congratulated "Ike" on his victory at the polls indicating, "My one great desire is to cooperate to the best of my ability in the tremendous job . . . in reestablishing sound and trustworthy government in the country." ${ }^{34}$

During the Eisenhower years Hickenlooper tended to modify his "hawk" stance to support the president's attempt to moderate the cold war. But in 1953 Hickenlooper opposed Charles Bohlen's appointment as ambassador to the USSR because of the latter's role at the Yalta conference in formulating what the Iowan regarded as the "sell out" of Poland. Also after the Army-McCarthy hearings, when President Eisenhower worked behind the scenes for Senate censure of McCarthy, Hickenlooper remained loyal to the Wisconsinite. Explaining why he voted against McCarthy's condemnation, Hickenlooper asserted: "I was one who felt that facts justifying the so-called censure of Senator McCarthy had not been established to the point of warranting censure. I said at the time that I disagreed with and criticized certain things which Senator McCarthy had

33. Hickenlooper to Dulles, 1 May 1953, "Publications of Foreign Relations," BBHP.

34. Hickenlooper to Eisenhower, 10 November 1952, "Political Campaigns of 1952," BBHP. 
said, but I could not bring myself to vote for his official censure." ${ }^{35}$

Hickenlooper admired John Foster Dulles and therefore supported key aspects of the Eisenhower administration's foreign policy. Where once he had disapproved of any foreign aid to a Communist nation, he now supported both economic and military assistance to Yugoslavia to bolster Marshall Tito's independence from Moscow. He also approved formation of the Southeast Asia Treaty Organization and voted for military and economic support to Middle East countries to buttress nonCommunist governments. He even voted for ratification of the Antarctica Treaty in 1950 in which the United States and eleven other nations, including the Soviet Union, agreed to peaceful use of that region. After Dulles died in 1959, Hickenlooper maintained that it was the former's "policies of firmness, toughness, and strength which really brought Soviet aggression to a standstill." ${ }^{36}$

Hickenlooper's final term in the Senate coincided with America's increasing involvement in Vietnam. He was one of the sponsors of the Southeast Asia (Gulf of Tonkin) Resolution in 1964 giving President Lyndon B. Johnson authority to "take all necessary measures to repel any armed attack against the forces of the United States and to prevent further aggression. ${ }^{\prime \prime} 37$ Although once referring to Vietnam as "quicksand" from which the United States must extricate itself, ${ }^{38}$ he nevertheless defended the escalation of United States intervention with his own version of the domino theory:

The stakes are too high, so far as future world peace is concerned, tragic though our losses may be, for the United States to now permit communist success in South Vietnam, as it would immediately threaten ... the Philippines, Australia, the whole Pacific

35. Quoted in Roy Cohn, McCarthy (New York, 1968), 237.

36. Hickenlooper to Robert W. Turner, 8 July 1959, "Foreign Relations-Bohlen, Charles E., 1953-1964," BBHP.

37. Lyndon Baines Johnson, The Vantage Point: Perspectives of the Presidency, 1963-1969 (New York, 1971), 117-118. Other sponsors included J. William Fulbright, chair of the Foreign Relations Committee; Richard Russell; and Leverett Saltonstall. The latter two were respectively chair and ranking Republican member of the Armed Service Committee.

38. Quoted in Time, 13 August 1965. 


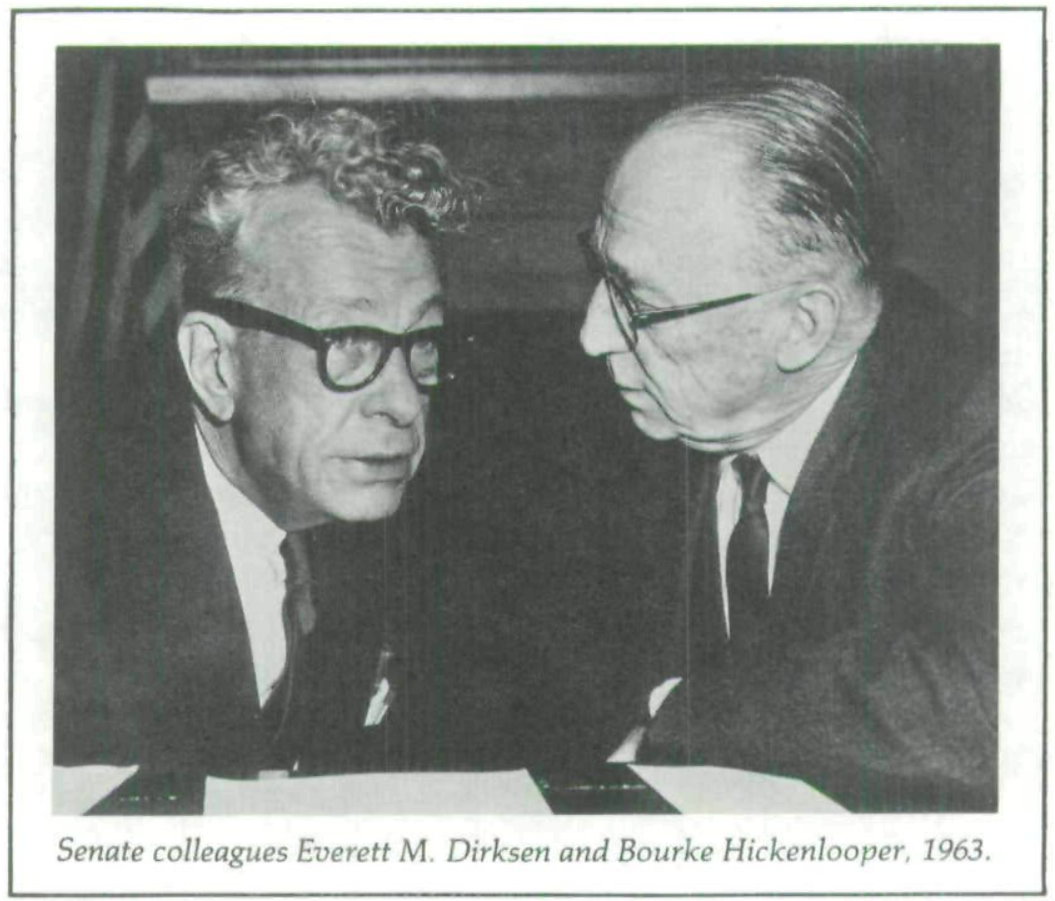

area and have devastating adverse influence on the newly developing nation-states of Africa, the Middle East and Latin America. ${ }^{39}$

Hickenlooper never changed his "hawk" stance regarding the Vietnam conflict. He doggedly insisted there was "no other course, in the interest of our own security and that of the free world, except to win it." He believed the war had to be fought to a successful military victory so that the "principles of selfdetermination and freedom for the peoples of Southeast Asia are protected and the North Vietnamese aggression halted." When Senator Jacob K. Javits of New York suggested debate on possible revision of the Southeast Asia Resolution, Hickenlooper admonished his colleague: "Frankly, I think this would add a tremendous amount of fuel to the fire and . . . provide a field day for those who have been so highly critical of that Resolution." Hickenlooper furthermore decried the activities of antiwar protesters. He contended that their protest marches

39. Hickenlooper to Mrs. R. M. Galt, 23 August 1965, "Viet Nam Correspondence," BBHP. 
aided and abetted the enemy by convincing "the Viet Cong, the Chinese, and the Russians that if they just hang on a while longer in Vietnam internal force will bring on a victory in Vietnam for the aggressor, North Vietnam and the Viet Cong." 40

The decision not to run for a fifth Senate term in 1968 was made not because Hickenlooper feared to face the Iowa electorate which he had served for thirty-three years, but because of his advanced age-seventy-three years-and because his wife, Verna, was ill. She died in 1970 and he on September 4, 1971. Fortunately for him, he did not live to witness the fall of South Vietnam to its Communist conquerors; this event would have grieved him deeply. In the realm of international relations Hickenlooper saw America's primary role as that of striving for the "preservation of freedom in the world." ${ }^{41}$ That the United States should do less was unthinkable to him. He was a man of sustained purpose who symbolized the unswerving stand of a generation called on repeatedly to fight, sacrifice, and even die for the defense of democracy in faraway places. His thinking did not change when the Vietnam War became unpopular.

During the national debate on Vietnam there were those who claimed that Hickenlooper's old-fashioned patriotism was not only archaic and simplistic, but actually harmful to the nation's real security. The label "cold war warrior" became a denigrating designation within the neo-isolationist atmosphere of the post-Vietnam era. Always skeptical of Kremlin intentions, Bourke Hickenlooper wrote a friend, "It is interesting to note that so long as we had a firm, consistent, strong, yet openminded, policy the Russians made almost no gains and seemed to be moving more toward an accommodation with the West." 42

In retrospect a strong argument can be made that Hickenlooper overreacted to the cold war. If there was an area in

40. Hickenlooper to Cliff Anderson, 2 August 1965, "Viet Nam Correspondence, 1965-1966," BBHP; Hickenlooper to Pat Austin, 13 January 1966, ibid.; Hickenlooper to Javits, 15 November 1967, "Viet Nam-Tonkin Gulf, 1967-1968," BBHP; Hickenlooper to Mrs. Francis A. Lackner, 28 March 1968, "Viet Nam Correspondence, 1968," BBHP.

41. Cedar Rapids Gazette, 6 October 1961, quoted in Memorial Addresses, 44.

42. Hickenlooper to W. Earl Hall, 11 June 1963, "Legislation-Arms Control and Disarmament Act, 1963-1964," BBHP. 
which he was a zealot, it was in the realm of preserving the internal security of the country and ensuring the containment of Communism abroad. Nevertheless, he reflected an anti-Communist mentality applauded by his constituency and held foreign policy views similar to other midwestern Republicans of the time..$^{43}$ The fact also remains that the fear and tension fostered by Communist gains after World War II were more alarming to a generation that regarded Soviet Communism as the totalitarian successor to Germany's Naziism. If Hickenlooper was single-minded and overly zealous in his determination to protect the American way of life and to defend the principle of self-determination throughout the world, he erred due to an intense patriotism and a belief that the "American century" should become a reality. That illusion has faded, but Bourke Hickenlooper, an exemplary cold war warrior, strove for nearly a quarter of a century to make it come true. His actions might be challenged but not his motives. He was, as Representative H. R. Gross observed in paying tribute to him, a persistent "strong voice for keeping America strong." ${ }^{44}$

43. Midwestern Republicans in this genre included Kenneth Wherry and Roman Hruska of Nebraska, Alexander Wiley of Wisconsin, Homer E. Capehart of Indiana, George Wilson of Iowa, Everett M. Dirksen of Illinois, and Homer Ferguson of Michigan.

44. Des Moines Register, 9 September 1971, quoted in Memorial Addresses, 36. 
Copyright of Annals of Iowa is the property of State of Iowa, by \& through the State Historical Society of Iowa and its content may not be copied or emailed to multiple sites or posted to a listserv without the copyright holder's express written permission. However, users may print, download, or email articles for individual use. 